\title{
The Exploration of the Inter-Disciplinary English Majors' English Writing Teaching under Big Data
}

\author{
Yu Zixun* \\ Humanistic Management Department, Changchun \\ University of Chinese Medicine \\ Changchun, China \\ e-mail: arnold0110@sina.com \\ * Corresponding Author
}

\begin{abstract}
Big Data is the resource for people to obtain new cogitation and create initiative and also a method to change business markets, organizations or institutions and the relationship between the government and citizens. In the Big Data era, the data bank has a great impact on the interdisciplinary English majors' English writing teaching mode. This paper discusses the opportunities and challenges of the inter-disciplinary English majors' English writing teaching mode, emphasizing that the humanistic education should be covered in the process of English writing process. The teachers utilize the data information technology to develop modern course courser in order to improve students' writing on the whole and foster humanistic qualities. The research elucidates the advantages of the linguistic materials from the Big Data and further differentiates the possible lack of humanistic education relying on the vast Big Data. The revolution of teachers' role switches from lecturer to guider, from instructor to supporter, from grader to referee.
\end{abstract}

Keywords-Big Data; English writing; teachers' role; teaching mode; humanistic education

\section{INTRODUCTION}

Big date is applied wholly in the field of business and city security with a lot of successful cases, the data determines a far-reaching impact on education. Compared with the traditional condition for the English teaching and learning, the development of computer, network and multimedia technology have brought a new teaching mode and a broaden space. For the traditional English writing, the students compose their writing based on the Chinese mode of thinking and then translate them into Chinese. The students are limited as their English proficiency is not satisfactory and their life experience is not profound. The teacher provides enclosed auxiliary and evaluation for the students. Therefore, both the English wiring and the evaluation of the writing are passive. In the Big data era, relevant data can be easily obtained, students who are in the process of writing are always limited to their life experience and bonded courses. In the Big data era, relevant data can be easily obtained; students can access to the more related information of their writing and then make full utilization of data.

Research on computer-mediated communication (CMC) has shown that the Internet has the potential to provide students with both a sense of empowerment and development of communication abilities. An increasing

\author{
Zhang $\mathrm{Na}$ \\ College of Art and Design \\ Shenyang Jianzhu University \\ Shenyang, China
}

number of language teachers and researchers ,e.g. , Belisle, Day \& Baston, Gongleweski, Meloni\& Brant and Ho, explore how to best utilize the Internet to facilitate EFL/ESL writing, which, as Schultz suggested, is one of the most compelling areas of exploration for computer use. Combined the Big date, the teachers are not the only benefactors and via them to use the new technology as a tool in their writing lecture to the students, the students should also be the direct shareholders of the Big Data era. This paper studies on the Big Data-based EFL/ESL writing instructions, and investigate the role of Big-Data assisted writing teaching in the following aspects:

(1) Pedagogical benefits of Big-Data based writing instruction for inter-disciplinary English major students and

(2) Limitations of Big-Data based writing instructions of the inter-disciplinary English major students

\section{PEDAGOGICAL BENEFITS OF BIG-DATA BASED WRITING INSTRUCTIONS FOR INTER- DISCIPLINARY ENGLISH MAJOR STUDENTS}

The language learning environment, as an essential factor of a theory of CALL, has changed under Big-Data context. Then, how could teachers and students utilize this new technology in English writing?

Along with the development of the Big Data, which covers a huge amount of functions and causes a strong impact on the traditional way of thinking, the students' traditional way of thinking should keep pace the new change. Writing is the most direct way for the output of one's thinking. The students as thinking subject, the writing content as thinking object and the thinking agent should be reevaluated.

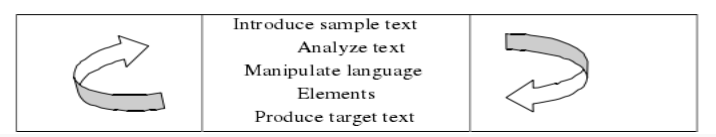

Figure 1. example of English writing thinking process

\section{A. The students' initiative writing mode.}

In the traditional writing class, the teachers are the source of knowledge and they provided certain pattern before the students' writing. The students accepted the teachers' instructions and wrote in a way to satisfy the teachers teaching purpose, the much similar with the 
teachers' pattern, the higher grade the students achieved. That pedagogical way is not benefit for the students in Big Data era. With Big Data, teachers and course books are not the only reliable sources for students, the material is abundant and equal for every learners. Whenever the students have motivations and inspirations for writing, they can access the relevant information to confirm and search for what they need. Initiative writing habit should be fostered under the teachers' instruction and it doesn't mean that the students can neglect the writing principles.

The learning environment is an essential factor for writing. As studies demonstrate that there are eight constructs for the convenience of observation and analysis (1) opportunities for learners to interact and to negotiate meaning; (2) an authentic audience; (3) authentic tasks; (4) opportunities for exposure to and production of rich and varied language; (5) opportunities for learners to formulate ideas and thoughts; (6) learners intentional cognition; (7) an ideal-anxiety atmosphere; (8) learner control. [1]

Based on these eight constructs, this section presents studies on Big Data-based writing instruction, examines and explores the pedagogical benefits of use Big Data for inter-disciplinary English major students' writing instruction, and investigates them under the following headings: (1) creative writing interaction with a variety of real audience; (2) authentic tasks for more language exposure and language output; (3) Multiple opportunities for formulating ideas and thoughts; (4) Multiple motivation to engage in learning; and (5) students control and an ideal-anxiety atmosphere. [2]

The inter-disciplinary English major students can be roughly divided into two categories according to their inclination about their two majors; some prefer English to the other major and vice verse. The students have more input of their compound major, but the teacher may not interest in it or just understand that subject superficially. Under the help of Big-Data, English writing teachers supple and update certain knowledge of their students' interest and keep pace with their other subjects.

\section{$B$. The students' Application of initiative writing mode}

In the information era, the inter-disciplinary English major student can access to the Big Data on their own. Inter-disciplinary English majors confront an embarrassing situation which is their English writing teachers are lack of their compound major's knowledge and their compound major's teachers' English proficiency may not be low. At present, if the data-driven learning method is practiced in the English writing for the interdisciplinary English majors. The students can avail themselves to search for linguistic materials, as the materials are spontaneous from the native speakers, the students in China can keep pace with the world. By the materials they seek from the data bank, they may have vast, punctual and relevant materials as input. The English writing teachers would be served as supervisors to discriminate and select data. The advantage is that the students can integrate English and their compound major together. Students' interest for writing as an output would be triggered by the autonomous reading from Big Data. The students' writing would be more relevant to their compound major and they can benefit from English writing by improving linguistic level and compound major as well. In a word, DDL provide effective and efficient input for the inter-disciplinary English majors and an opportunity to share their wring as an output to more audiences. By this way, the students have opportunities to make network friends who are English native peers share similar interests. They can restore the old tradition of pen friendship and they would write more regularly and willingly. It is more appealing to writing when there is a response than just handing the papers to teachers for grade. The students write as thinking subjects and initiate more creative ideas. Along with the Big Data, even the students with low level English writing proficiency and because of which they would dislike English writing, they could access themselves to the materials they interest in and achieve a certain amount of reading as input. By reading autonomously, the students cognition in English would be formulated; the students' master of frequent used English pattern would be increased unintentionally; the students' basic logic ability would be improved; the students' vocabulary in real context would be enlarged; the students' self-confidence towards English would be collected. All in all, in the era of Big-Data, students of different levels benefit from data-driven learning.

The teachers' role is still significant, from lecturers to demonstrate writing techniques to guiders who assist students to make an attempt for their individual style; from instructors to order all the students to write the same topic to pioneers who encourage the students to search from the materials and decide their own topic to write; from graders to referees who evaluate the students dynamic performance.

As the author analyzes, in the Big Data era, the interdisciplinary students' writing is tend to be self-organized and autonomous. In the English writing class, the teachers are not the only authorities. They guide the students how to access reliable linguistic materials from the corpus, especially the writings from the author of native Englishspeaking countries. The students must confront a huge amount of problems to be solved. Then, the teachers transfer to assistants to lead the students to solve the problems under the help of Big Data. Instead of providing "important writing skills and techniques to the students, the teachers become the guiders to delineate broaden perspectives. And for the passive students with less passion about English writing, the teachers should guide the students their interest field and select certain materials for such students and even guide them to read at first. For the active students with ambition for English writing, the teachers do not need to border to restrict a topic for them to write. With the Big Data, evaluation of the English writing is revolutionized. Teachers can utilize Big Data technology to analyze students' writings, and the detailed comments and feed backs would be given in a short time. At last, teachers help students to correct the mistakes online. So, the teachers are referees to some extent.

\section{LIMITATIONS OF BIG-DATA BASED WRITING INSTRUCTIONS FOR INTER- DISCIPLINARY ENGLISH MAJORS}

The academic authorities of the humanities agree with that foreign language is not only a tool, but conveying sufficient humanity. It should be a humanity discipline, a social science. When it is manipulated for interaction and 
communication, the language must convey information, thoughts, emotions and so on, which express the humanity and humanity discipline characteristics.

Therefore, the English writing is the most direct way to demonstrate students' inner world. The English writing course is not only aimed at improving students' skills, and more significantly, it is a part of quality education, especially concerning about the students' attitudes towards life, the students' searching for their ego and according to which they can form positive outlook on life and values. The English writing represents the organic unification of both instrumentality and humanity. The English writing course means more for the interdisciplinary English majors because they apply English writing to the other major. Therefore, the English writing course inter-disciplinary English majors focuses on the humanity spirit and the course undertakes the humanity education. In the process of the English writing class, if the teachers leave the students open to the Big Data, the students tend to seek novel stimulus and latest news. In the Big Data era, their purposes for writing are from selfinterest or sharing personal experiences and emotions. Although these are from their bottom of heart, they are too of the self or personal or superficial. With the convenience of Big Data, the students are voracious scanners for various updated information, the youngsters incline to keep pace with the changing world. As a result, the students gain a large amount of information, but they do not cherish the corpus compared with the traditional readers. There are merely students reluctant to read a certain linguistic material several times for better understanding and then digest them into their own writing. So, even if they select sublime and optimistic linguistic materials, the students with less patience can not gain the nutrition from them to avail themselves of humanity education. Their students' English writings are fancy flowers without roots. In the daily English writing class, teachers foster the student ability to utilize the corpus, but also highly concern the humanity education in the process of writing. When evaluating the writing papers, the teachers sense students' linguistic proficiency as well as their humanistic growth. The teachers guide the students with passive and isolated attitude life to other way. By further writing, the teachers gain feedback from their writings. The English writing teachers collect students' writing papers to master their thoughts, attitudes and behaviors and then the multiple evaluations which are the basis for humanistic qualities are achieved.

The inter-disciplinary English major are advantageous in the Big Data context because they look for both Chinese and English linguistic material. Then the possibility of cheating in their English writing is increased. Certain students find materials and imitate them without quotations. The humanistic education is more important for students who are exposed freely in the Big Data context. Teachers also absorb abundant materials from the Data Bank, but they analyze and organize to make full use by themselves. The students learn from the teachers' demonstration to better synthesize those materials instead of copying without thinking. Students' hesitation and doubts from certain corpus can be discussed in the class with the classmates and teacher. Teachers and students are fascinated about the Big Data, but they should value the face-to-face communication in daily life.

\section{CONCLUSIONS}

All in all, compared with traditional pedagogical English writing, the English writing under Big Data context is a vivid and time-effective mode. Teachers revolutionize pedagogical mode with the manipulation of high-tech and data-driven learning to construct a multipledimensional class system. Along with the new mode, teachers leading student think actively and take some initiations immerse humanistic education in English writing. After broadening students' outlook and the depth of thoughts, the teachers and students can obtain the western and Chinese essence by comparing the different cultures. With regular writing, students' comprehensive cultural qualities and autonomous study ability are improved. Humanistic education is a principle section in English writing and an inevitable part in college English teaching. Big Data provides opportunities and constricts for English writing teaching. The requirements for the English teachers are more challenging than before. Teachers' role is changing, and only by the changed roles, teachers provide new mode of English writing class mode. Teachers guide and assist students to form correct outlook of life and values. The humanistic foundation is primary for the inter-disciplinary English majors. Students' English writing with the assistance of data provides them the opportunity to gain more humanistic education and comprehensive qualities which are necessary for the social talents.

\section{ACKNOWLEDGEMENT}

Upon the completion of this paper, I would like to extend my sincere gratitude to those who have assisted and supported me during the process of my research and writing.

First and foremost, I am especially appreciating our Dean, Professor He Zhanyi, for his insightful guidance and supports for the reform in the Inter-Disciplinary English Major's Writing Teaching Mode. Then I would like to extend special thanks for my student participants who cherish their time for corpus based on Big Data and provide written and oral feedback to me simultaneously.

\section{REFERENCES}

[1] Swain, M. L. Brooks, \& A. Tocalli-Belller. Peer-peer Dialogue as a Means of Second Language Learning [J]. Annal Review of Applied Linguistics, 2002,(22): 171-185

[2] Vyatkina, N.A. Development of Second Language Pragmatic Competence: the Data Driven Teaching of German Modal Practices Based on a Learner Corpus [D].Unpublished dissertation. Pennsylvania State University, University Park, 2007 :109-132.

[3] Bachman, L. Fundamental Considerations in Language Testing [M].Oxford: Oxford University Press, 1990:109-132.

[4] Nunan, D. \& Bailey, K.M. Exploring Second Language Classroom Research: A Comprehensive Guide [M]. Beijing: Foreign Language Teaching and Research Press, 2009.

[5] Nunan, D. Second Language Teaching and Learning [M]. Beijing:

Foreign Language Teaching and Research Press, 2009.

[6] O' KEEFFE, A., McCarthy, M. \& Carter, R. From Corpus to Classroom: Language use and Language Teaching [M].Cambridge: Cambridge University Press, 2007. 
[7] Davies, P. \& Pearse, E. Success in English Teaching [M]. Oxford: Oxford University Press, 2000 .

[8] Eccles, J. S., Wigfield, A. Motivational beliefs, values, and goals [J]. Annual Review of Psychology, 2008

[9] Vilamil, O.S.\& M.C.M de Guerrero.. Peer revision in the L2 classroom: Social-cognitive activities, mediating strategies, and aspects of social behavior [J]. Jounal of Second Language Writing, 1996,5
[9] Vygotsky, L. S. Thought and Language [M]. Cambridge, MA: MIT Press, 1986.

[10] Vygotsky, L. S. Mind in Society: The Development of Higher Psychological Processes [M]. Cambridge:

Harvard University Press, 1989

[11]Reid, J. Writing [A]. In The Cambridge guide to teaching English to speakers of other language [C]. R.

Carter \& D. Nunan (Ed.). Cambridge: Cambridge University Press, 2001: 